\title{
EVALUATION OF MODCLARK MODEL FOR SIMULATING RAINFALL-RUNOFF IN TANGRAH WATERSHED, IRAN
}

\author{
GHARIB, M. ${ }^{1}$ - MotAMEdVAZIRI, B. ${ }^{1 *}$ - GHERMEZChEShMEH, B. ${ }^{2}-$ AhMADI, H. ${ }^{1}$ \\ ${ }^{I}$ Department of Watershed Management, Science and Research Branch, Islamic Azad \\ University, Tehran, Iran
}

${ }^{2}$ Soil Conservation and Watershed Management Institute, Agricultural Research, Education and Extension Organization (AREEO), Tehran, Iran

*Corresponding author

e-mail: bmvaziri@gmail.com; phone: +98-912-483-6636

(Received $1^{\text {st }}$ Sep 2017; accepted $15^{\text {th }}$ Jan 2018)

\begin{abstract}
Rainfall-runoff hydrological models are one of the common methods for simulating flood hydrographs. These models come in three Lumped, semi-distributed and fully distributed scale, in terms of spatial accuracy in simulation in which precision increases with increasing spatial accuracy. ModClark model is a distributed model. The purpose of this study is to evaluate the efficiency and accuracy of the ModClark model in simulating flood hydrograph in Tangrah watershed located in Iran and comparing the rainfall-runoff simulated using this model and Soil Conservation Service (SCS) model. five rainfallrunoff events were extracted at Tangrah Station. Then, the parameters of the model were calibrated based on three observed hydrographs and validated based on two observed hydrographs. Finally, to evaluate the results of simulation of flood hydrograph after optimization, the Determination Coefficient $\left(\mathrm{R}^{2}\right)$ and Root Mean Square Error (RMSE) methods were used. The results of the model evaluation showed that ModClark with an RMSE of 1.55 and with an $\mathrm{R}^{2}$ of 0.84 , is more accurated and efficient than the SCS model in simulating flood hydrograph. Considering the high accuracy of ModClark distributed model, using this hydrologic model, we can study the interaction of physiographic and climatic factors on the potential of watersheds' runoff production.
\end{abstract}

Keywords: flood hydrographic, simulation, distributed model, ModClark

\section{Introduction}

Runoff is one of the most important hydrological variables used in many water resources applications. Reliable prediction of the amount of runoff flowing upland to rivers is difficult and time-consuming (Kumar et al., 2010). Rainfall-runoff hydrological models for flood hydrograph simulation are suitable methods for better flood management, especially in ungauged basins. In order to estimate the flood discharge, there are various models used in simulating the watershed response against rainfall and they include a variety of lump, quasi-distributed and distributed models (Saghafian et al., 2010). Today, with access to satellite imagery and map data, it is possible to simulate the response of a watershed to a rainfall with specific characteristics with the help of distributed models. Models in which the spatial distribution of rainfall characteristics and watersheds are taken into account are known as distributed hydrological models (Saghafian et al., 2010). Planning for controlling and managing the floods, maintaining the quality and their proper utilization requires an accurate understanding of rainfall-runoff modeling. The most important challenge of the model is the selection of a particular rainfall-runoff model which can simulate a wide range of floods. Water resources experts have always sought for the equation between rainfall and runoff values in watersheds and in different time and place conditions. To date, 
several rainfall-runoff models with different capabilities and complexities have been developed and used to predict floods. Several studies have been conducted on rainfallrunoff modeling. Ghitoto (1991) in his research on calculating runoff hydrograph, showed that in large basins, flood discharge generated by the SCS method is closer to the observed values. One-dimensional and two-dimensional numerical models used to predict the flood rise in the rivers were investigated by Horritt and Bates (2002). In this study, TELEMAC-2D, HEC-RAS and LISFOOD-FP models were compared in a 60$\mathrm{km}$ range of the Severn River. The results showed that the HEC-RAS and TELEMAC2D models can be calibrated by discharge, and the information of the water uplift area and flood area can be predicted. Emerson et al. (2003) developed a model for rainfallrunoff using the HEC-HMS model. From the results of the implementation of the model, the the storage levels are responsible for the reduction in the amount of peak flow for the storm event. Kathol et al. (2003) in order to determine peak flow and runoff in two agricultural basins in the southeastern state of South Dakota and by using the HEC-HMS model concluded that, the value of the curve number is of high sensitivity, while the initial loss rate is less sensitive than varying the value of the objective function in the HEC-HMS model. Foody et al. (2004) used the HEC-HMS model to simulate the flood in order to identify flood-sensitive areas in an area in western Egypt which led to the identification of two sensitive areas. Knebl et al. (2005) conducted a modeling of the flood streaming in the summer of 2002 using HEC-HMS and HECRAS software and radar data in the San Antonio Watershed in the United States. He used the ModClark method to convert rainfall into runoff and calibrated watershed parameters manually. The results indicated that the model was a suitable tool for regional hydrological forecasting in the basin. Khosroshahi and Saghafian (2005) investigated the response of Damavand watershed sub-basins using the HEC-HMS model. In this research, the contribution of each sub-basin was calculated in peak discharge of the output flood such that no single-variable relationship exist between the flood index and other characteristics of the sub-basins, including the curve number and ground gradient. Alvankar et al. (2006) examined the effect of cell size in calculating peak flood discharge in distributed models for simulating hydrograph of the watershed of Kan. Using the SCS penetration model, Clarck's developed clustering model for Geographic Information System (GIS)-based flood simulation was developed in the Visual Basic environment. The results of this study showed that by increasing the size of cells from $30 \times 30 \mathrm{~m}^{2}$ to $960 \times 960 \mathrm{~m}^{2}$, the flood peak discharge decreases. Teymouri et al. (2007) simulated the peak discharge of flood hydrograph using ModClark distribution method in Kasilian watershed. The results of this study indicate the high capability of HEC-HMS model in simulating the distribution method of peak flood discharge and the relatively efficient performance of this method in the studied basin. Sarangi et al. (2008) by comparing the geomorphology methods and curve numbers in ungauged basins to calculate direct runoff hydrographs found that, the geomorphology method is more appropriate in small watersheds with similar geomorphologic features. Studies by Linde et al. (2008) showed that distributive models were better than Lumped reality models in terms of showing the reality. Zhang et al. (2008) in China used the MIKE-SHE model to quantitative runoff simulation. Calibration and validation of the model showed that this model can well handle the runoff simulation in small basins. The appropriate scale plays an important role in calibrating the model, and the estimated value for the parameters is influenced by the time and space scales of input data of the model. Paudel et al. (2009) in a research using GIS, radar data and HEC-HMS 
hydrologic software compared both distributed and lump models. They used the ModClark distributed and Clarck lump models and the Curve Number Method in the casualty section for transfer. The results of this study showed that the use of any distributed, lump, real or artificial rainfall data is possible to enter the model. Also, using the same Curve Number (CN) values, the ModClark method showed better results than Clarck's method. Chidaz et al. (2009) used Snyder, SCS unit hydrograph and Clarck methods to estimate flood hydrograph in the Kasilian Watershed. Comparison of the results of these three methods showed that SCS unit hydrograph method is more suitable for predicting flood hydrograph compared to the other two methods. Saghafian et al. (2010) used the ModClark Distributed Rainfall-Runoff Model at the sub-basin level and the HEC-RAS model for hydraulic regeneration in the main river network. The intensity of flooding for $2 \times 2 \mathrm{~km}^{2}$ cell units was obtained by implementing "Unit Flood Response" method in the form of sequential removal of cells and simulation of flood hydrograph for rainfall design, and the effect of each cell on the total area outlet hydrograph was obtained. The results showed that the largest and closest sub-basins to the outlet, or the furthest and smallest, do not necessarily have the highest and lowest impact on the maximum flood discharge. In a study in India, two HEC-HMS and Water Erosion Prediction Project (WEPP) models used to simulate flow based on daily rainfall data were compared. In general, the HEC-HMS model was preferred to the WEPP model for daily flow simulation (Verma et al., 2010). Ghavidelfar et al. (2011) compared Clark lump and ModClark distributed models in the Randan watershed in Tehran province. The results showed that both models accurately simulate flood hydrograph. They argued that ModClark distributed model in the estimation of time to peak and runoff volume showed better results compared to peak discharge. Bhattacharya et al. (2012) in the article of ModClark Model investigated the development and application of the spatial distribution model of unit hydrograph. Their research results showed that the ModClark model is based on Clarck's unit hydrograph method which utilizes the NEXRAD rainfall network data, and the results of the calibration has been satisfactory. Shabanlou and Rajabi (2012) compared the ModClark distributed and SCS lump models in the Karoun watershed. Using the information and GIS maps of the region and using HEC-HMS software and the HEC-GeoHMS appendix, they simulated flood water. The results demonstrate the superiority of ModClark's distributed model compared to the lump SCS model in flood hydrograph simulation. Halwatura et al. (2013) To simulate runoff in the tropical region of Attanagalu Oya from the HEC-HMS model. Their research results showed that the Snyder's unit hydrograph method is more accurate in comparison with the Clarke unit hydrograph method in flow simulation. Shabanlou (2014) in a study titled Flood Hydrograph Calculation Using Different Methods in the Karun River simulated flood hydrograph in Karoun watershed using the SCS Model with HEC-HMS Software, and compared this model with the ModClark model using GIS with the use of both distributed and lump mathematical models, and from the field data the results of the distributed model are closer to the recorded hydrograph of the basin. Sampth et al. (2015) conducted a runoff simulation in the tropical region of the Deduru Oya River Basin in Sri Lanka using the HEC-HMS model. The results of this study showed that the HEC-HMS model with an $80 \%$ efficiency coefficient is able to simulate runoff and estimate the potential of inter-basin flow in this area, and is a suitable tool for managing water resources. Studies by Jiang et al. (2015), in relation to rainfall-runoff modeling, parameter estimation and sensitivity analysis in Luanhe Province, China, showed that 
the distributed model has a better performance than the Lumped model. Thomas and Roy (2016) investigated the comparison of hydrograph extraction in the Bharathapuzha River Basin. According to this study, because in most areas without statistics, the preparation and development of unit hydrograph is difficult, therefore, the incompatibility of observation simulator hydrograph can be attributed to the large area of the watershed. Saghafian et al. (2016), investigated A coupled Modclark-Curve number rainfall-runon-runoff model. In this Research, a novel rainfall-runon-runoff mathematical model is developed via Soil Conservation Service (SCS) infiltration and ModClark rainfall-runoff coupled models. After deriving model formulation, three different spatial patterns of curve number (uniform, downstream increasing, and decreasing) in conjunction with various rainfall durations and intensities were investigated under with and without runon scenarios over a V-shaped watershed. The results indicated that there was lower surface runoff volume and peak discharge in all cases when runon was accounted for. In particular, in regions with low curve number, there were major differences between the hydrographs simulated by the commonly practiced norunon model and the presented runon model. Moreover, the runon effect in case of decreasing curve number in downstream direction was more pronounced than that of the increasing case. However, this effect decreased with depth, intensity, and duration of rainfall. Rezaei et al. (2016) in their study entitled "Flood spatial variability" using the "Unit Flood Response" method in Khanmirza Basin concluded that, ModClark model simulates the peak discharge with high precision and this model has high accuracy in simulating flood hydrograph. In the sources, there are few studies on the comparison and accuracy of the ModClark model in Iran. The purpose of this study was to evaluate the efficiency and accuracy of the ModClark method in simulating flood hydrograph in Tangrah watershed located in Iran. Most important reasons of selecting Tangrah watershed for this study are the flooding potential and the high runoff production potential, the morphometric and morphological diversity of the region, the existence of an active hydrometric station in the catchment outlet, the existence of the active rexording rain gauge station inside the basin, the existence of a sufficient number of rainfall events with the presence of rainfall-runoff data in the area.

\section{Materials and methods}

\section{Study area}

Tangrah watershed with an area of $1860 \mathrm{~km}^{2}$ and an average height of $1398 \mathrm{~m}$ is a part of the Madrasou watershed in Iran country where the runoff from the basin flows through the Dough River to the Golestan dam (Fig. 1). This basin is divided into two parts: mountainous and plain, with a variety of morphological, morphometric, climatic and land use variations. The type of climatic of the region is classified as semi-arid to wet (Water Research Institute, 2010). Tangrah watershed area has two hydrometric stations of Dasht and Tangrah such that, the only hydrometric station of Tangrah has limnograph and long term statistical period and the Rain gauge Station of Golestan National Park is the only station with sufficient statistics inside the basin. Therefore, the hydrometric station of Tangrah was used as the basis for comparing the hydrograph of model simulation and observation hydrograph for calibration and validation of the model. Figure 2 shows the elevation digital model of the study area. 


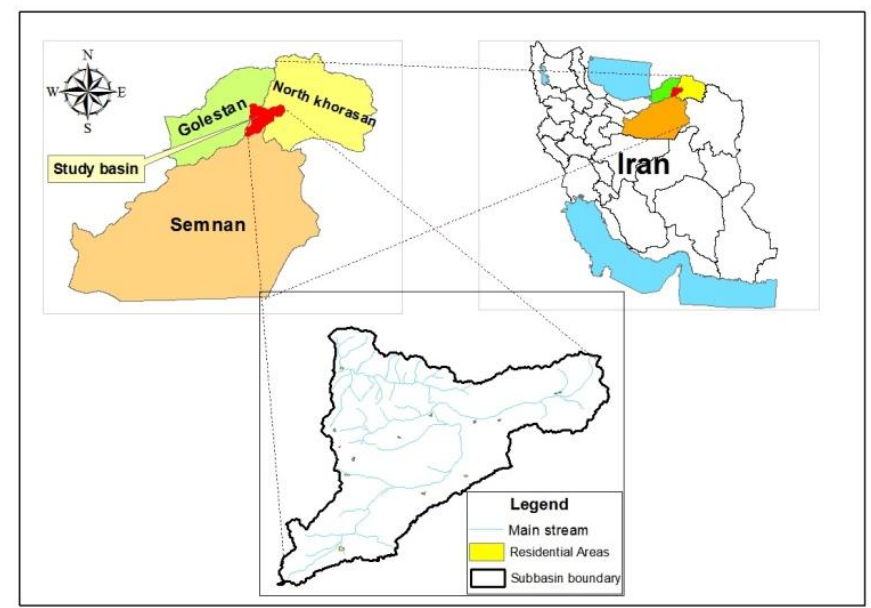

Figure 1. Position of research area (Madarsou, Tangrah watershed and Dough river)

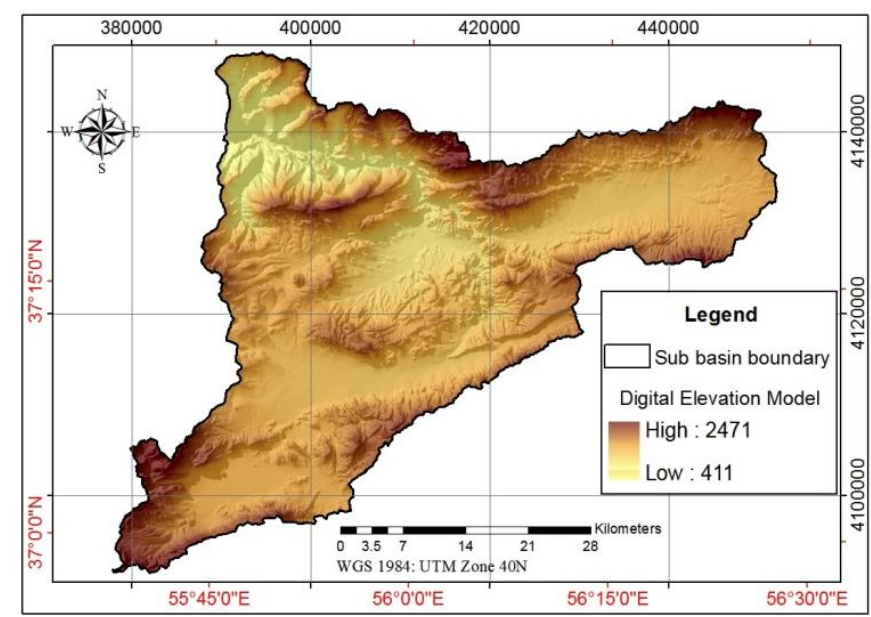

Figure 2. Elevation digital model map of Tangrah watershed

\section{Research methodology}

In this study, two methods of SCS and ModClark were evaluated. In the HEC-HMS module, various methods of runoff simulation have been modeled and recognized as valid modules. This modulus can be executed for Iran in order to simulate runoff with the ModClark method. The ModClark method is a quasi-distributed method and should be more precise than lump methods. This methodology was programmed by Alvankar (2003).

The SCS method is a unit instantaneous hydrograph. SCS unit hydrograph is a dimensionless and single-peak method. In this approach, for the conversion of rainfall into runoff using the SCS lump method, the CN value is imported into the model (US Army Engineers Group, 2000). The US Soil Conservation Agency has made it possible to access the initial values of some of the parameters considering the physiographic properties of the basin. In this connection, a relationship between concentration time and lag time has been proposed, where $t_{c}$ is the concentration time and $t_{\text {lag }}$ is lag time of the basin. One of the inputs of the HEC-HMS model in this method is the lag time parameter $\mathrm{t}_{\text {lag }}(E q .1)$. 


$$
t_{\text {lag }}=0.6 t_{c}
$$

This model is conducted on the HEC-HMS software; this software uses a unit t-hour hydrograph and additional rainfall height at each interval, which is equivalent to the continuity of the hydrograph, to calculate the flood hydrograph.

The ModClark Distributed Hydrograph Model was developed by Peters and Easton in 1996. This developed model is a Clarck rainfall-runoff model in which the spatial distribution of rainfall is taken into account. ModClark model includes time-distributed area and a linear reservoir (Paudel et al., 2009). The most important differences between these two methods are how to rout and simulate the nature of the flow reservoir. In the Clarck method, all isochronous regions are modeled with a linear reservoir while in the ModClark method each of the individual isochronous regions is routed separately (Figure. 3).

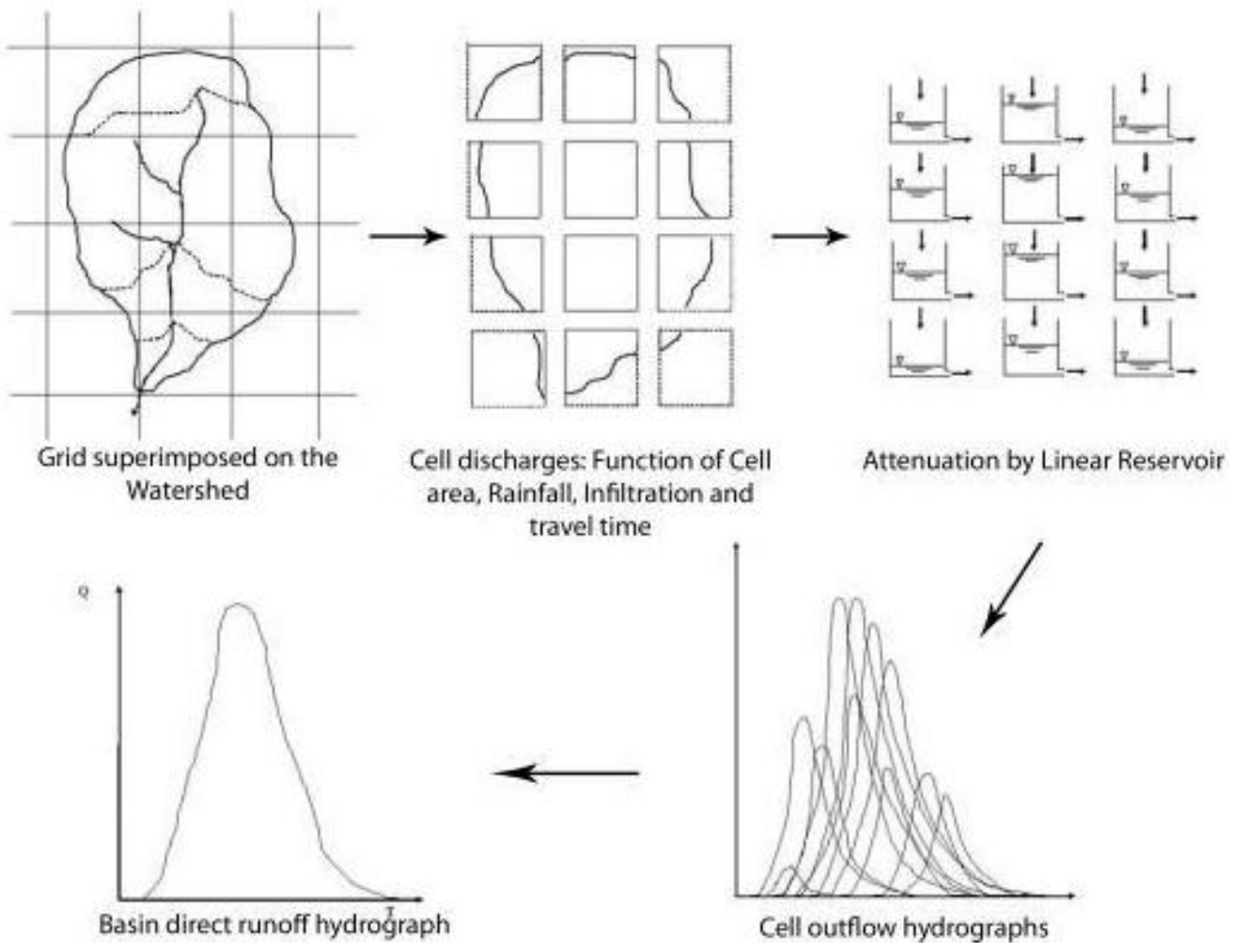

Figure 3. ModClark conceptual model (Kull and Feldman, 1998)

In this method, the travel time is calculated for all cells in a basin. The travel time of each cell to the basin outlet is proposed in relation to (Eq. 2) (Kull and Feldman, 1998).

$$
T_{\text {cell }}=T_{c} \frac{L_{\text {cell }}}{L_{\max }}
$$

where: $T_{\text {cell }}$ is the travel time from each cell to the basin outlet, $T_{c}$ is the concentration time of the basin, $\mathrm{L}_{\text {cell }}$ is the distance between each cell to the basin outlet and $\mathrm{L}_{\max }$ is the maximum length of the water flow in the basin. In this method, the effective rainfall in each cell with the lag time is proportional to the length of the movement of that cell 
to the outlet of the basin. In this model, it is not necessary to determine the coefficient of roughness on the ground and the depth of the subcortical flow, and the estimation of the hydrograph is conducted with the help of two main parameters, the concentration time and the Clarck storage factor. Runoff height is calculated in each step using the spatial distribution map of rainfall and the $\mathrm{CN}$ map in each cell. Then, in the next step, the runoff depth of each cell is routed according to the time of the cell's movement to the output. In the final step, the obtained hydrograph is routed according to the relationship in the linear reservoir (Eq. 3).

$$
S_{(\mathrm{t})}=K O_{(t)}
$$

where $\mathrm{S}_{(\mathrm{t})}$ is storage at time $\mathrm{t}, \mathrm{O}_{(\mathrm{t})}$ is the output of the reservoir at time $\mathrm{t}$ and $\mathrm{K}$ is the Clarck storage coefficient.

In order to simulate flood hydrograph with the aforementioned methods, topographic, land use and soil hydrological group maps were prepared in GIS environment. A map of the region's curve number was obtained by integrating the land use map with the hydrologic group of soil (Fig. 4).

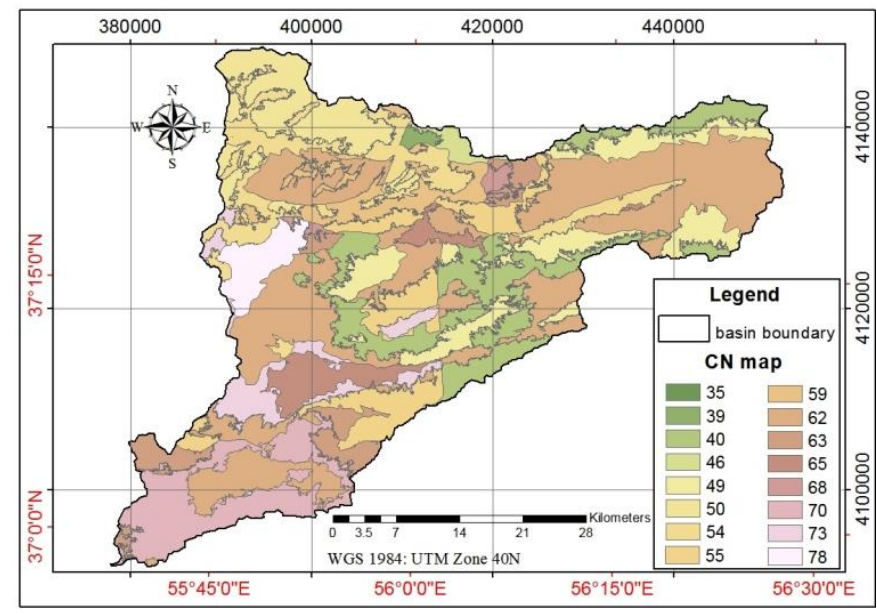

Figure 4. Map of curve number of Tangrah Watershed in moderate humidity

At this stage, after investigation of observed flood hydrographs, 5 events with available rainfalls were selected. Since the rainfall generating each flood hydrograph must be entered into the model to simulate the flood hydrograph, in order to determine the flood generating rainfall, in the history of each event, the rainfall distribution was extracted using the daily rainfall recorded at the rain guage stations in and around the study area, using the Inverse Distance Weighted (IDW) method in the GIS environment. The time distribution of the storms was determined from the Recording rain gauge station data of the Golestan National Park. After preparing the map of the area's curve number, effective rainfall and initial loss, the SCS method was used based on the following relationships (Eqs. 4, 5 and 6):

$$
S=\frac{25400}{C N}-2540
$$




$$
\begin{gathered}
\mathrm{P}_{\mathrm{e}}=\frac{\left(p-I_{a}\right)^{2}}{\mathrm{p}-\mathrm{I}_{\mathrm{a}}+\mathrm{S}} \\
\mathrm{I}_{\mathrm{a}}=a \cdot S
\end{gathered}
$$

where $\mathrm{P}_{\mathrm{e}}$ is the effective rainfall height in $\mathrm{mm}, \mathrm{P}$ represents Rainfall height in $\mathrm{mm}, \mathrm{S}$ is Maximum reservoir potential in $\mathrm{mm}, \mathrm{CN}$ is the average weight curve of the basin, $\mathrm{I}_{\mathrm{a}}$ is the initial loss in $\mathrm{mm}$ and a is a coefficient of 0.2 .

The concentration time was calculated by using Bransby Williams method. This relationship has been recommended for basins larger than 50 square miles (Eq. 7).

$$
T C=\frac{L}{1.5 D} \sqrt[5]{\frac{M^{2}}{F}}
$$

where $\mathrm{L}$ is the Main waterway length $(\mathrm{km})$, D represents Circle equivalent diameter $(\mathrm{km}), \mathrm{M}^{2}$ is the area of the basin (sq. Km), and $\mathrm{F}$ is the mean waterway slope (percent). The parameters required for each of these methods are presented in Table 1 after calculating the aforementioned equations.

Finally, after providing the aforementioned information for the implementation of SCS model, basin model, meteorological model (hygrograph of each rainfall) and control characteristics (curve number, initial loss, concentration time, lag time) were defined in HEC-HMS software. After completing and entering the data, the HEC-HMS model was used for rainfall-runoff observation data and simulation hydrograph. To calibrate and validate the model, events were divided into two categories such that, three were selected for calibration and two events were selected for validation. During the model calibration process, the input parameters of the model were optimized for each event. Calibrated parameters of three events were averaged and used as input parameters for two validation events.

For simulating flood by the ModClark method, Flood module developed by Alvankar (2003) in the Visual Basic environment was used. After providing the digital data about rainfall, curve number and flow path length, Raster map of these parameters was provided in the GIS environment and then entered into the Flood model. The time distribution of rainfall was also used from the Recording rain gauge station data of Golestan National Park. To determine the movement distance of each cell to the outlet of the basin, the DEM of the basin was used and the movement distance of each cell to the basin outlet was calculated. It should be noted that the concentration time of the watershed indicates the time of water flow from the farthest cell to the outlet of the basin. Input parameters of $\mathrm{CN}$ index, the initial losses, concentration time and reserve coefficient were calculated. It should be noted that the reserve coefficient was used graphically (Viessman et al., 1972) and it was used as a preliminary estimation in the calibration step. The steps to implement the model are shown in Figure 5.

In the ModClark method, five events with rainfall/runoff data were selected for rainfall-runoff simulation.

\section{Evaluation of the model efficiency}

In this research, to evaluate the results of simulation of flood hydrograph after optimization, the determination coefficient $\left(\mathrm{R}^{2}\right)$ and Root Mean Square Error (RMSE) were used. The general formula for these two statistics is shown in the following 
relationships (Eq. 8 and 9). Finally, the best simulation belongs to the rainstorm with the maximum efficiency or lower RMSE.

$$
\begin{gathered}
\text { RMSE }=\sqrt{\left(\frac{1}{n} \sum_{i=1}^{n}\left[\left(O_{o}\right)-\left(Q_{E}\right)\right]^{2}\right)} \\
R^{2}=\frac{\left(\sum_{i=1}^{n}\left(Q_{o}-Q_{\text {Ave }}\right)\left(Q_{E}-Q_{\text {Ave-E }}\right)^{2}\right.}{\sum_{i=1}^{n}\left(Q_{O}-Q_{\text {Ave }}\right)^{2}\left(\sum_{i=1}^{n}\left(Q_{E}-Q_{\text {Ave }-E}\right)^{2}\right.}
\end{gathered}
$$

In these equations $\mathrm{O}_{O}$ and $\mathrm{Q}_{\mathrm{E}}$ are, respectively the values of observation and simulation data $\left(\mathrm{Q}_{\mathrm{o}}\right.$ : observed discharge, $\mathrm{Q}_{\mathrm{E}}$ : simulated discharge), $\mathrm{Q}_{\text {Ave }}$ : mean of observed discharge, $\mathrm{Q}_{\mathrm{Ave}-\mathrm{E}}$ : mean of simulated discharge and $\mathrm{n}$ the number of data. Finally, after calibrating and validating using ModClark and SCS methods, the results of the data analysis were evaluated based on the two methods of statistical analysis of the determination coefficient (R2) and Root Mean Square Error (RMSE).

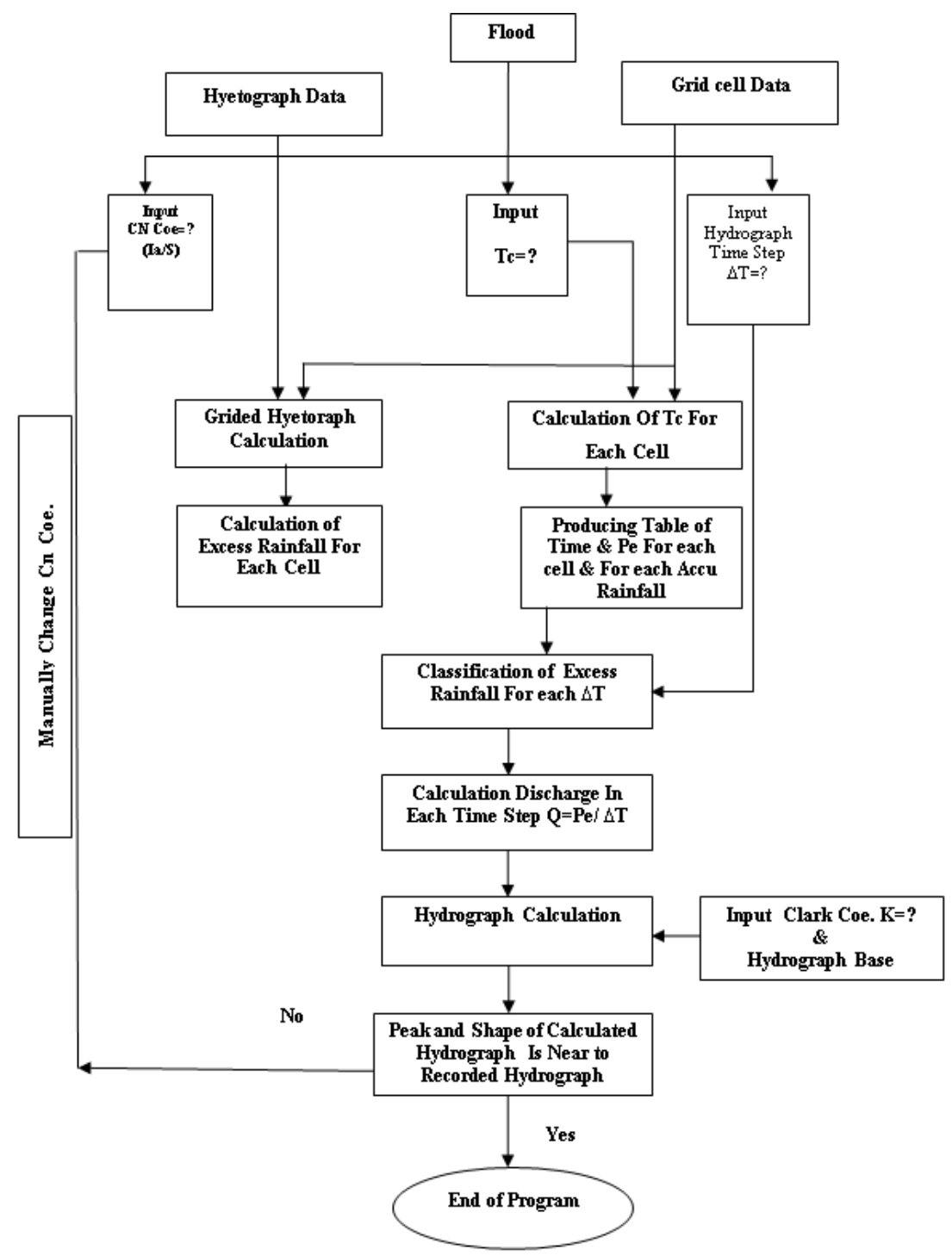

Figure 5. Flowchart of methods in the ModClark method 


\section{Results}

In this study, the efficiency of the ModClark method and SCS for 5 events was compared. The SCS method was implemented in HEC-HMS software and the ModClark method in Flood software. The optimized values of the model parameters are presented in Table 1.

Table 1. Primary and optimized parameters in different events in the HEC-HMS software

\begin{tabular}{|c|c|c|c|c|c|c|c|}
\hline \multicolumn{3}{|c|}{ Optimized parameter values } & \multicolumn{3}{|c|}{ Initial parameter values } & \multirow[b]{2}{*}{ Subbasin } & \multirow[b]{2}{*}{ Event date } \\
\hline$\underset{(\min )}{\text { Lag time }}$ & $\begin{array}{c}\text { Curve } \\
\text { number } \\
\text { (CN) }\end{array}$ & $\begin{array}{l}\text { Initial } \\
\text { losses } \\
(\mathbf{m m})\end{array}$ & $\underset{(\min )}{\text { Lag time }}$ & $\begin{array}{c}\text { Curve } \\
\text { number } \\
\text { (CN) }\end{array}$ & $\begin{array}{l}\text { Initial } \\
\text { losses } \\
(\mathbf{m m})\end{array}$ & & \\
\hline 1080 & 59.9 & 34 & 1080 & 59.9 & 34 & Nardin & \\
\hline 660 & 55.44 & 40.83 & 660 & 55.44 & 40.83 & Cheshmehkhan & $\begin{array}{c}1999.04 .08 \\
\text { validation }\end{array}$ \\
\hline 623.98 & 81.714 & 37.354 & 540 & 54.69 & 42.08 & Tangrah & \\
\hline 1080 & 77.42 & 14.81 & 1080 & 77.42 & 14.81 & Nardin & \\
\hline 660 & 74.1 & 17.75 & 660 & 74.1 & 17.75 & Cheshmehkhan & $\begin{array}{l}2003.05 .25 \\
\text { calibration }\end{array}$ \\
\hline 540 & 73.52 & 18.29 & 540 & 73.52 & 18.29 & Tangrah & \\
\hline 1090.2 & 74.354 & 14.938 & 1080 & 77.42 & 14.81 & Nardin & \\
\hline 660 & 74.1 & 17.75 & 660 & 74.1 & 17.75 & Cheshmehkhan & $\begin{array}{l}2004.05 .05 \\
\text { calibration }\end{array}$ \\
\hline 346.28 & 61.96 & 10.808 & 540 & 73.52 & 18.29 & Tangrah & \\
\hline 1080 & 59.9 & 34 & 1080 & 59.9 & 34 & Nardin & \\
\hline 660 & 55.44 & 40.83 & 660 & 55.44 & 40.83 & Cheshmehkhan & $\begin{array}{l}2004.09 .18 \\
\text { calibration }\end{array}$ \\
\hline 560.85 & 42.916 & 42.703 & 540 & 54.69 & 42.08 & Tangrah & \\
\hline 1080 & 77.42 & 14.81 & 1080 & 77.42 & 14.81 & Nardin & \\
\hline 660 & 74.1 & 17.75 & 660 & 74.1 & 17.75 & Cheshmehkhan & $\begin{array}{c}\text { 2006.04.08 } \\
\text { validation }\end{array}$ \\
\hline 817.73 & 97.798 & 17.799 & 540 & 73.52 & 18.29 & Tangrah & \\
\hline
\end{tabular}

With frequently running model, the hydrologic model and comparison of observed and simulated hydrographs, the hydrologic parameters of the basin varied sufficiently such that the error value obtained from the difference in the peak discharge of the observable and simulated hydrograph peak was minimized. Table 2 shows the output results in different events in the SCS method. According to Table 2, in the event of 2004.5.5, the values of model R2 and RMSE in the SCS method are estimated to be 0.88 and 1.8, respectively. Based on the results of the table, the difference between peak flow and flood volume is estimated to be $4.5 \mathrm{~m}^{3} \mathrm{~s}^{-1}$ and $760 \mathrm{~m}^{3}$, respectively. Figure 6 shows the observed and simulated hydrograph using the SCS method in the events of 2003.5.25 and 2004.9.18. The parameters required for simulating of hydrograph in ModClark method shown in Table 3 represent before and after calibration.

The results of calibration of the model and optimization of the parameters and observation of simulated and observed hydrograph changes verified that, curve number parameters, initial loss and lag time in SCS and CN coefficients, initial loss and $\mathrm{K}$ coefficients in the ModClark model showed the most change compared to the primary. 
Table 2. Percentage of observed flood and simulation characteristics differences in calibration and validation stage in HEC-HMS software

\begin{tabular}{|c|c|c|c|c|c|c|c|c|}
\hline RMSE & $\begin{array}{c}\text { Determination } \\
\text { coefficient } \\
\left(\mathbf{R}^{2}\right)\end{array}$ & $\begin{array}{c}\text { Correlation } \\
\text { coefficient } \\
\text { (R) }\end{array}$ & $\begin{array}{l}\text { Difference } \\
\text { percentage }\end{array}$ & Difference & Simulated & Observed & Parameter & $\begin{array}{l}\text { Event } \\
\text { date }\end{array}$ \\
\hline \multirow[b]{2}{*}{22.8} & \multirow[b]{2}{*}{0.12} & \multirow[b]{2}{*}{0.34} & -33.30 & -380.5 & 762.1 & 1142.6 & $\begin{array}{c}\text { Volume } \\
\left(1000 \mathrm{~m}^{3}\right)\end{array}$ & \multirow{2}{*}{$\begin{array}{l}1999.04 .08 \\
\text { validation }\end{array}$} \\
\hline & & & 0.2 & 0.1 & 13.5 & 13.4 & $\begin{array}{c}\text { Peak } \\
\text { discharge } \\
\left(\mathrm{m}^{3} \mathrm{~s}^{-1}\right)\end{array}$ & \\
\hline \multirow[b]{2}{*}{12.7} & \multirow[b]{2}{*}{0.41} & \multirow[b]{2}{*}{0.638} & 41.92 & 3111 & 10532.8 & 7421.8 & $\begin{array}{c}\text { Volume } \\
\left(1000 \mathrm{~m}^{3}\right)\end{array}$ & \multirow{2}{*}{$\begin{array}{l}2003.05 .25 \\
\text { calibration }\end{array}$} \\
\hline & & & 27.7 & 22.7 & 104.9 & 82.2 & $\begin{array}{c}\text { Peak } \\
\text { discharge } \\
\left(\mathrm{m}^{3} \mathrm{~s}^{-1}\right)\end{array}$ & \\
\hline \multirow[b]{2}{*}{1.8} & \multirow[b]{2}{*}{0.88} & \multirow[b]{2}{*}{0.943} & 0.76 & 13 & 1721.7 & 1708.6 & $\begin{array}{l}\text { Volume } \\
\left(1000 \mathrm{~m}^{3}\right)\end{array}$ & \multirow{2}{*}{$\begin{array}{l}2004.05 .05 \\
\text { calibration }\end{array}$} \\
\hline & & & 4.5 & 1.3 & 31.1 & 29.8 & $\begin{array}{c}\text { Peak } \\
\text { discharge } \\
\left(\mathrm{m}^{3} \mathrm{~s}^{-1}\right)\end{array}$ & \\
\hline \multirow[b]{2}{*}{5.2} & \multirow[b]{2}{*}{3.02} & \multirow[b]{2}{*}{-1.738} & 89.28 & 764.2 & 1620.1 & 855.9 & $\begin{array}{c}\text { Volume } \\
\left(1000 \mathrm{~m}^{3}\right)\end{array}$ & \multirow{2}{*}{$\begin{array}{l}2004.09 .18 \\
\text { calibration }\end{array}$} \\
\hline & & & 185.5 & 19.6 & 30.2 & 10.6 & $\begin{array}{c}\text { Peak } \\
\text { discharge } \\
\left(\mathrm{m}^{3} \mathrm{~s}^{-1}\right)\end{array}$ & \\
\hline \multirow[b]{2}{*}{0.8} & \multirow[b]{2}{*}{0.86} & \multirow[b]{2}{*}{0.93} & -64.93 & -158 & 85.3 & 243.3 & $\begin{array}{c}\text { Volume } \\
\left(1000 \mathrm{~m}^{3}\right)\end{array}$ & \multirow{2}{*}{$\begin{array}{c}2006.04 .08 \\
\text { validation }\end{array}$} \\
\hline & & & -50.5 & -1.3 & 1.2 & 2.5 & $\begin{array}{c}\text { Peak } \\
\text { discharge } \\
\left(\mathrm{m}^{3} \mathrm{~s}^{-1}\right)\end{array}$ & \\
\hline
\end{tabular}

Table 3. Hydrological parameters of Tangrah watershed area after calibration and validation in the ModClark method

\begin{tabular}{c|c|c|c|c|c|c|c|c}
\hline \multicolumn{2}{c|}{ CN coefficient } & \multicolumn{2}{c|}{$\begin{array}{c}\text { Reserve coefficient } \\
(\mathbf{h})\end{array}$} & \multicolumn{2}{c|}{$\begin{array}{c}\text { Initial losses ratio } \\
\left(\boldsymbol{I}_{\boldsymbol{a}} / \boldsymbol{s}\right)\end{array}$} & \multicolumn{2}{c|}{$\begin{array}{c}\text { Concentration time } \\
(\mathbf{h})\end{array}$} & \multirow{2}{*}{$\begin{array}{c}\text { Event } \\
\text { date }\end{array}$} \\
\cline { 1 - 7 } $\begin{array}{c}\text { After } \\
\text { calibration }\end{array}$ & $\begin{array}{c}\text { Before } \\
\text { calibration }\end{array}$ & $\begin{array}{c}\text { After } \\
\text { calibration }\end{array}$ & $\begin{array}{c}\text { Before } \\
\text { calibration }\end{array}$ & $\begin{array}{c}\text { After } \\
\text { calibration }\end{array}$ & $\begin{array}{c}\text { Before } \\
\text { calibration }\end{array}$ & $\begin{array}{c}\text { After } \\
\text { calibration }\end{array}$ & $\begin{array}{c}\text { Before } \\
\text { calibration }\end{array}$ & \\
\hline 1.1 & 1.2 & 23.2 & 25.93 & 0.15 & 0.2 & 25.93 & 25.93 & 1999.04 .08 \\
1 & 1.012 & 24.1 & 25.93 & 0.16 & 0.2 & 25.93 & 25.93 & 2003.05 .25 \\
1.21 & 1 & 24.5 & 25.93 & 0.14 & 0.2 & 25.93 & 25.93 & 2004.05 .05 \\
1.09 & 1 & 21.1 & 25.93 & 0.15 & 0.2 & 25.93 & 25.93 & 2004.09 .18 \\
1.1 & 1.2 & 23.2 & 25.93 & 0.15 & 0.2 & 25.93 & 25.93 & 2006.04 .08 \\
\hline
\end{tabular}

Table 4 shows the values of the simulation results evaluation in different methods of SCS and ModClark. Based on the results of Table 4, in the 2003.5.25 event, the RMSE in the SCS and ModClark methods have values of 12.7 and 11.77, respectively, and the R2 in the SCS and ModClark method have values of 0.41 and 0.46 , respectively. According to the above two parameters, the ModClark method has been simulated more accurately than the SCS method. 
Table 4. Estimates of simulation results in different ModClark and SCS methods

\begin{tabular}{c|c|c|c}
\hline RMSE & $\mathbf{R}^{\mathbf{2}}$ & Used model & Event date \\
\hline 22.8 & 0.12 & $\begin{array}{c}\text { SCS } \\
\text { ModClark }\end{array}$ & 1999.04 .08 validation \\
2.81 & 0.74 & $\begin{array}{c}\text { SCS } \\
\text { ModClark }\end{array}$ & 2003.05 .25 calibration \\
\hline 12.7 & 0.41 & SCS & 2004.05 .05 calibration \\
11.72 & 0.46 & ModClark & 2004.09 .18 calibration \\
\hline 1.8 & 0.88 & SCS & 2006.04 .08 validation \\
\hline 9.96 & 0.79 & ModClark & SCS \\
\hline 5.2 & 3.02 & ModClark &
\end{tabular}

Figure 6 shows the observed and simulated hydrographs by the ModClark and SCS methods on 2003.5.25 (at calibration stage) and Figure 7 shows the observed and simulated hydrographs by the ModClark and SCS methods on 2006.4.8 data (in the validation step). In Table 5, the results of the evaluation of the SCS and ModClark models are presented in the flood peak estimation at the validation step.

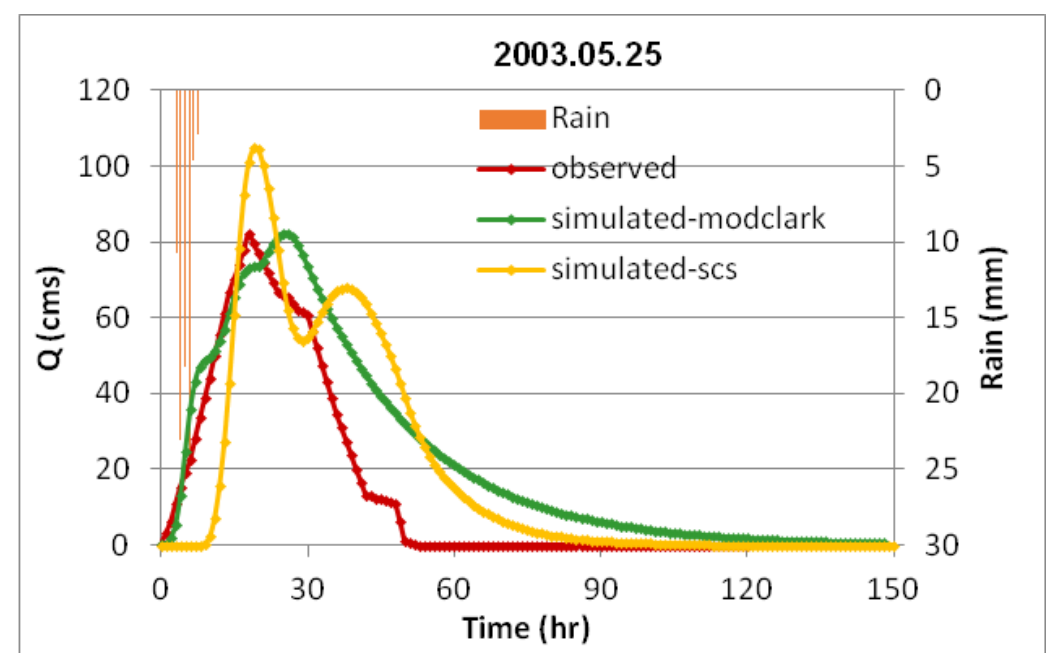

Figure 6. Observed and simulated hydrograph by ModClark and SCS methods on 2003.5.25 (calibration)

Table 5. The results of the evaluation of the SCS and ModClark models in estimating flood peak discharge at the validation step

\begin{tabular}{c|c|c|c}
\hline RMSE & $\mathbf{R}^{\mathbf{2}}$ & Used model & Event date \\
\hline 0.74 & 2.81 & 1999.04 .08 & \multirow{2}{*}{ Mod-Clark validation } \\
\hline 0.93 & 0.28 & 2006.04 .08 & Mean of Mod-Clark validation \\
\hline 0.84 & 1.55 & \multirow{2}{*}{ SCS validation } \\
\hline 0.12 & 22.8 & 1999.04 .08 & \\
\hline 0.86 & 0.8 & 2006.04 .08 & \multicolumn{2}{c}{ Mean of SCS validation } \\
\hline 0.49 & 11.8 & \multicolumn{2}{c|}{}
\end{tabular}




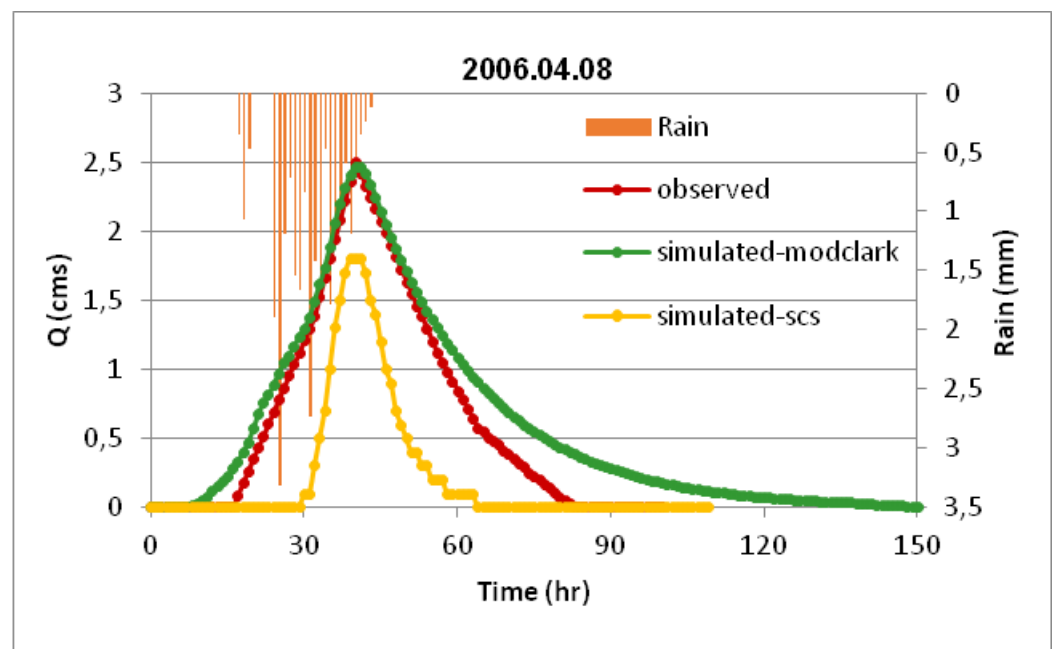

Figure 7. Observed and simulated hydrographs by ModClark and SCS methods on 2006.4.8 (validation)

\section{Discussion and conclusion}

The results of calibration and optimization of this study showed that, the ModClark method is superior to the SCS method for estimating peak flow of flood hydrograph (Table 4). In terms of peak discharge estimation, the least difference between the peak discharge of simulations and observations is associated with the ModClark method (Table 5). The survey on model parameters shows that the curve number parameter and initial losses in the SCS model (Table 1) and the parameters of curve number and initial losses and reserve coefficient in the ModClark model are highly sensitive, provided the other parameters are less sensitive than changing the value of the objective function in the above models (Table 3).

The results of comparison of discharge showed that the ModClark model in the validation step simulated the flood hydrograph with RMSE and the R2 values of 1.55 and 0.84, respectively and the ModClark model has the best fitness between the observed and simulated data compared to the SCS method. Also, in terms of peak Flow estimation, the ModClark method also has a lower predictive error. This suggests that the simulation of flood hydrographs works better in the ModClark method. The reason for this is based on the concept of linear reservoir model and considering the parameter of the K Muskingum coefficient. The SCS method depends greatly on the calibration due to the dependence on the empirical relationships. So the error is very high. The lowest RMSE is associated with the ModClark method. Therefore, this method is well suited for estimating equilibrium flows. Eventually, events simulated by the ModClark method have the best fitness with real conditions (Fig. 7). The most important point in the research is that, in modest humidity conditions with $\mathrm{CN} 2$, better and more accurate results are obtained than wet and dry conditions. the results of this study are consistent with the results of Saghafian et al. (2010), Ghavidelfar et al. (2011), Shabanlou (2014) and Rezaei et al. (2016).

By comparing the parameters RMSE and the $\mathrm{R}^{2}$ (Table 4), in both calibration and validation stages, ModClark method has lower mean squared errors and a more accurate R2 than the SCS method. Given that, the more closer the root mean square error is to zero and the R2, the more accurate the model is in flood hydrograph simulation. The 
ModClark method has RMSE and $\mathrm{R}^{2}$ values more accurate than the SCS method and the results of this study are consistent with the results of Knebl et al. (2005), Alvankar et al. (2006), Paudel et al. (2009), Saghafian et al. (2010), Ghavidelfar et al. (2011), Shabanlou and Rajabi (2012) and Jiang (2015) based on well suited capability of the ModClark model for estimating the flood hydrograph.

Finally, the result of this research was shown ModClark distributed model has better accuracy of SCS model, so this model can be used in determining of flooding area. Considering the high accuracy of ModClark model, using this hydrologic model, we can study the interaction of physiographic and climatic factors on the potential of watersheds' runoff production. Also the results showed that because the use of the ModClark model requires highly precise inputs, therefore; it is possible to use this method in very important tasks such as determining areas with high runoff potential in very small units. Since the SCS-CN penetration estimation method is sensitive to the depth of precipitation, it is suggested that other methods of infiltration be used. It is suggested that considering the different conditions in watersheds with various climate conditions and different geomorphology, the efficiency of ModClark model in more watersheds of the country should be considered in order to determine the applicability; and considering the high sensitivity of the model with the $\mathrm{CN}$ parameter, this method will be further investigated in different areas of the country. It is recommended to use other distributed models for rainfall-runoff simulating and compare with the present study.

\section{REFERENCES}

[1] Alvankar, S. R. (2003): Distributed model of flood simulation Using GIS. - Phd dissertation on irrigation. Islamic Azad University, Science and Research Branch of Tehran (in Persian).

[2] Alvankar, S. R., Saghafian, B., Sedghi, H. (2006): Effect of pixel size of a hydrologic model on simulation of flood peak. - Journal of Agricultural Sciences Islamic Azad University 12(2): 329-344 (in Persian).

[3] Bhattacharya, A. K., McEnroe, B. M., Zhao, H., Kumar, D., Shinde, S. (2012): Modclark model: improvement and application. - IOSR Journal of Engineering (IOSRJEN) 2(7): $100-118$.

[4] Chidaz, A., Mohseni Saravi, M., Vafakhah, M. (2009): Evaluating the HEC-HMS model for estimating flood hydrograph in Kasilian basin. - Journal of Watershed Management Researches (Pajouhesh and Sazandegi) 84: 59-71 (in Persian).

[5] Emerson, C. H., Welty, C., Traver, R. G. (2003): Application of HEC-HMS to model the additive effects of multiple detention basins over a range of measured storm volumes. Civil Engineering Database. Part of World Water \& Environmental Resources Congress 2003 and Related Symposia.

[6] Foody, G. M., Ghoneim, E. M., Arnell, N. W. (2004): Predicting locations sensitive to flash flooding in an arid environment. - Journal of Hydrology 292(1-4): 48-58. DOI: 10.1016/j.jhydrol.2003.12.045.

[7] Ghavidelfar, S. Alvandkar, S. R., Razmkhah, A. (2011): Comparison of the lumped and quasi-disributed Clark runoff models in simulating flood hydrographs on a semi-arid watershed. - Water Resources Management 25(6): 1775-1790. DOI: 10.1007/s11269011-9774-5.

[8] Ghitoto, R. D. (1991): Runoff hydrograph computation method. - A designer course at Clarion Palaz Hotel. 
[9] Halwatura, D., Najim, M. M. M. (2013): Application of the HEC-HMS model for runoff simulation in a tropical catchment. - Environmental Modelling \& Software (46): 155162. DOI: 10.1016/J.envsoft.2013.03.006.

[10] Horritt M. S., Bates, P. D. (2002): Evaluation of 1D and 2D numerical models for predicting river flood inundation. - Journal of Hydrology 268: 87-99.

[11] Jiang, Y., Liu, C. M., Li, X. Y, Liu, L. F., Wang, H. R. (2015): Rainfall-runoff modeling, parameter estimation and sensitivity analysis in a semiarid catchment. - Environmental Modelling \& Software (67): 72-88. DOI: 10.1016/J.envsoft.2015.01.008.

[12] Kathol, J. P., Werner, H. D., Trooien, T. P. (2003): Predicting Runoff for Frequency based storm Using a Prediction Runoff Model. - A.S.A.E., South Dakota, U.S.A.

[13] Knebl, M. R., Yang, Z. L., Hutchison, K., Maidment, D. R. (2005): Regional Scale flood modeling using NEXRAD, rainfall, GIS, and HEC-HMS\RAS: a case study for the San Antonio River basin summer 2002 storm event. - Journal of Environmental Management 75: 325-336. DOI: 10.1016/j.jenvman.2004.11.024.

[14] Kull, D. W., Feldman, A. D. (1998): Evaluation of Clark's unit graph method to spatially distributed runoff. - Journal of Hydrologic Engineering ASCE 3(1): 9-19.

[15] Kumar, P. S., Ratna, K. B. M. J., Praveen, T. V., Venkata, K. V. (2010): Analysis of the runoff for watershed using SCS-CN method and geographic information systems. International Journal of Engineering Science and Technology 2: 3947-3654.

[16] Linde, A. H. te, Aerts, J. C. J. H., Hurkmans, R. T. W. L., Eberle, M. (2008): Comparing model performance of two rainfall-runoff models in the Rhine basin using different atmospheric forcing data sets, hydrology and earth system sciences. - 12(2008): 943-957.

[17] Paudel, M., Nelson, E. J., Scharffenberg, W. (2009): Comparision of lumped and quasidistributed Clark runoff models using the SCS curve number equation. - Journal of Hydrology Engineering ASCE 34(3): 1098-1106. DOI: 10.1061/ASCE_HE.19435584.0000100.

[18] Peters, L., Easton, D. (1996): Runoff simulation using radar rainfall data. - Water Resource Bulletin AWRA 32(4): 753-760.

[19] Rezaei, M., Vafakhah M., Ghermezcheshmeh, B. (2016): Spatial variability using a flood response method in Khanmiriza watershed. - Scientific-Research Journal of Engineering and Watershed Management 8(1): 150-139 (in Persian).

[20] Roy, A., Thomas, R. (2016): A comparative study on the derivation of unit hydrograph for Bharathapuzha River Basin. - Procedia Technology, International Conference on Emerging Trends in Engineering, Science and Thechnology (ICETEST-2015) 24: 62-69.

[21] Saghafian, B., Khosroshahi, M. (2005): Unit response approach for priority determination of flood source areas. - Journal of Hydrologic Engineering ASCE 10(4): 270-277. DOI: 10.1061/(ASCE)1084-0699.

[22] Saghafian, B., Ghermezcheshmeh, B., Kheirkhah, M. M. (2010): Iso-flood severity mapping: a new tools for distributed flood source identification. - Natural Hazards 55(2): 557-570. DOI: 10.1007/s11069-010-9547-0.

[23] Saghafian, B., Noroozpour, S., Kiani, M., Rafieei Nasab, A. (2016): A coupled Modclark-curve number rainfall-runon-runoff model. - Arabian Journal of Geosciences 9(4): 277. DOI: $10.1007 / \mathrm{s} 12517-015-2295-4$.

[24] Sampth, D. S., Weerakoon, S. B., Herath, S. (2015): HEC-HMS model for runoff simulation in a tropical catchment with intra-basin divisions. Case study of the Deduru Oya River Basin, Sri Lanka. - Engineer 48(1): 1-9.

[25] Sarangi, A., Singh, D. K., Singh, A. K. (2008): Evaluation of curve number and geomorphology-based models for surface runoff prediction from ungauged watersheds. Current Science 94(12): 1620-1626.

[26] Shabanlou, S. (2014): Calculation of flood hydrograph for karun basin by different methods. - Agricultural Communications 2(2): 54-61. 
[27] Shabanlou, S., Rajabi, A. (2012): Comparison of estimated flood hydrographs using lumped and distributed models. - Journal of Environmental Research and Development 7(1): 79-87.

[28] Teymouri, M., Habibnejad, R. M., Ghanbarpour, M. R., Abbasi, A. A. (2007): Simulation of peak discharge of flood hydrograph using ModClark distribution method. - Journal of Agricultural Science and Natural Resources of Khazar 1(5): 29-42 (in Persian).

[29] US Army Corps of Engineers (2000): Hydrologic modeling system. HEC-HMS: Technical Reference Manuals. - Hydrologic Engineers Center, Davis, CA, USA.

[30] Verma, A. K., Jha, M. K., Mahana, R. K. (2010): Evaluation of HEC-HMS and WEPP for simulating watershed runoff using remote sensing and geographical information system. - Paddy and Water Environment 8: 131-144. DOI: 10.1007/s10333-009-0192-8.

[31] Viessman, W., Harbaugh, T. E., Knapp, J. (1972): Introduction to Hydrology. - Intext Ed. Pub., New York.

[32] Water Research Institute. (2010): Project Reports of Gorganroud Flood Warning System. - Water Resources Department, Tehran.

[33] Zhang, Z., Wang S. W., Sun, G., Steven, G. M., Zhang, H., Jianlao, M., Eduard, K., Strauss, P. (2008): Evaluation of the MIKE SHE Model for application in the Loess Plateau China. - American Water Resources Association 44(5): 1108-1120. 